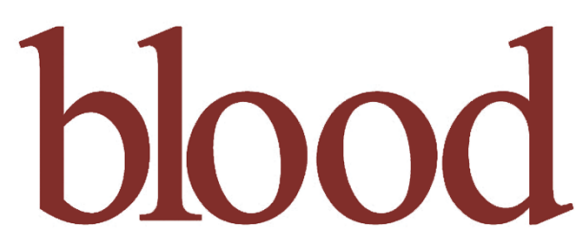

Prepublished online August 23, 2012;

doi:10.1182/blood-2012-04-424184

\title{
Erythrocyte density in sickle cell syndromes is associated with specific clinical manifestations and hemolysis
}

Pablo Bartolucci, Carlo Brugnara, Armando Teixeira-Pinto, Serge Pissard, Kamran Moradkhani, Hélène Jouault and Frederic Galacteros

Information about reproducing this article in parts or in its entirety may be found online at:

http://bloodjournal.hematologylibrary.org/site/misc/rights.xhtml\#repub_requests

Information about ordering reprints may be found online at:

http://bloodjournal.hematologylibrary.org/site/misc/rights.xhtml\#reprints

Information about subscriptions and ASH membership may be found online at:

http://bloodjournal.hematologylibrary.org/site/subscriptions/index.xhtml

Advance online articles have been peer reviewed and accepted for publication but have not yet appeared in the paper journal (edited, typeset versions may be posted when available prior to final publication). Advance online articles are citable and establish publication priority; they are indexed by PubMed from initial publication. Citations to Advance online articles must include the digital object identifier (DOls) and date of initial publication.

Blood (print ISSN 0006-4971, online ISSN 1528-0020), is published weekly by the American Society of Hematology, 2021 L St, NW, Suite 900, Washington DC 20036.

Copyright 2011 by The American Society of Hematology; all rights reserved.

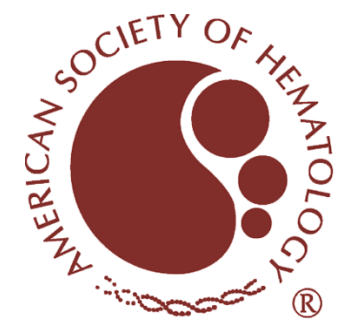


Erythrocyte density in sickle cell syndromes is associated with specific clinical manifestations and hemolysis

Short title: Correlates of red cell density

Pablo Bartolucci, ${ }^{1,2,3}$ Carlo Brugnara,${ }^{4, \star}$ Armando Teixeira-Pinto, ${ }^{5}$ Serge Pissard, ${ }^{6}$ Kamran Moradkhani, ${ }^{6}$ Hélène Jouault, ${ }^{7}$ and Frederic Galacteros. ${ }^{1,2,3}$

${ }^{1}$ Service de Médecine Interne, Hôpital Henri-Mondor, Assistance Publique-Hôpitaux de Paris (AP-HP), Université Paris Est, Créteil, France; ${ }^{2}$ Centre de Référence des syndromes drépanocytaires majeurs, Hôpital Henri-Mondor, AP-HP, Université Paris Est,Créteil, France ; ${ }^{3}$ INSERM U955 ; ${ }^{4}$ Department of Laboratory Medicine, Children's Hospital Boston, Boston, MA, USA; ${ }^{5}$ Department of Biostatistics and Medical Informatics, Faculty of Medicine University of Porto, Porto, Portugal; ${ }^{6}$ Service de Biochimie, Hôpital Henri-Mondor, AP-HP, Université Paris Est, Créteil, France ;

${ }^{7}$ Service d'Hématologie Biologique, Hôpital Henri-Mondor, AP-HP, Université Paris Est, Créteil, France.

${ }^{*}$ Correspondence: Carlo Brugnara, MD, Children's Hospital Boston, Department of Laboratory Medicine. 300 Longwood Avenue, BA 760. Boston, MA 02115, USA. carlo.brugnara@childrens.harvard.edu.Phone:617.355.6610; Fax: 617.730.0383

Scientific section designation: RED CELLS, IRON, AND ERYTHROPOIESIS 


\section{Abstract}

Dense, dehydrated red blood cells (DRBCs) are a characteristic feature of sicklecell disease (SCD). DRBCs play a role in the pathophysiology of SCD acute and chronic organ damage because of heightened tendency to undergo polymerization and sickling due to their higher $\mathrm{HbS}$ concentration. Relationships between red cell density (assessed with phthalate density-distribution profile method) and several hematologic, biochemical, genetic parameters and clinical manifestations were studied in a large cohort of homozygous patients. The \%DRBC was significantly higher in patients who experienced skin ulcers, priapism or renal dysfunction. Presence of a-thalassemia deletions was associated with fewer DRBCs. A multivariable analysis model showed DRBCs to be positively associated with hemolytic parameters like lactate dehydrogenase and bilirubin and negatively with fetal hemoglobin. The \%DRBC decreased by $34 \%$ at 6 months of hydroxycarbamide (xydroxyurea) therapy. Thus, DRBCs are associated with specific clinical manifestations and biological markers, and may be a useful addition to the biologic and clinical evaluation of SCD patients, since they can easily be measured in a hematocrit tube. 


\section{Introduction}

All homozygous patients with sickle-cell disease (SCD) carry the same genetic defect in the B-globin genes. However, the clinical presentation and overall severity of their disease vary greatly, from milder forms that can go undetected for decades to extremely severe forms with multi-organ damage and early mortality. Identification of risk factor(s) and laboratory parameters that might be predictive of SCD severity or complications has important implications not only for understanding the pathophysiology of the disease but also for clinical management.

A distinguishing characteristic of SCD is erythrocyte dehydration, due to $\mathrm{K}^{+}$efflux from the red blood cell (RBC) and consequently decreased intracellular water content and increased mean corpuscular hemoglobin concentration $(\mathrm{MCHC}){ }^{1,2}$ Eaton and coworkers demonstrated that the rate of the initial polymerization phase depends on the $20^{\text {th }}-40^{\text {th }}$ power of $\mathrm{HbS}$ concentration. ${ }^{3} \mathrm{HbS}$ polymerization and sickling rates can be substantially reduced with relatively small diminutions of the intracellular $\mathrm{HbS}$ concentration. $^{3}$ 4,5 Notably, in dense RBC (DRBC), defined as having a density exceeding 1.120 , the intracellular total $\mathrm{Hb}$ concentration is increased from the normal ( $33 \mathrm{~g} / \mathrm{dL}$ ) to $40-50 \mathrm{~g} / \mathrm{dL} .{ }^{6}$ DRBC exhibit increased rigidity and decreased stability, and include a variable fraction of irreversibly sickled cells (ISC) ${ }^{7,8}$

The DRBC fraction varies within most SCD patients with wide inter-patient variations. ${ }^{6,9}$ However, in earlier reports, no correlations could be established between DRBCs and clinical SCD severity. Most of those published studies were underpowered to detect this kind of interaction, which requires very large numbers of well-characterized patients, and yielded contradictory findings. ${ }^{10,11}$ Moreover DRBCs have never been studied for 
their potential association with chronic organ damage which is increasing being observed today because of the recent improvements in life expectancy.

Similarly, the lack of precise clinical correlates for the \%DRBC has not allowed assessing the potential additional indications for hydroxycarbamide (HC, hydroxyurea), which is currently indicated for the prevention of vaso occlusive crises (VOC) or acute chest syndrome (ACS).

Herein we compared data on RBC density with clinical, and hematological, biochemical and genetic parameters in a large cohort of homozygous SCD adult patients with the goal of identifying association with phenotypes and parameters indicative of severity. This population is unique for representing African immigrants with little Caucasian admixture and little admixture of haplotypes, contrary to what is seen in American patients.

We also studied the effect of hydroxycarbamide on the \%DRBCs. 


\section{Materials and methods}

\section{Patients}

All SS SCD patients regularly followed in our Center for Sickle Cell Disease at the Hopital Henri Mondor (Creteil, France), for whom a RBC density measurement was available before hydrocarbamide treatment or blood transfusional exchange therapy, were included in this cohort study of the Center's clinical and laboratory database. For each patient, sex, age, weight, height, body mass index and geographic origin were recorded. All clinical data were considered when prospectively collected. Renal dysfunction was defined as proteinuria $>0.3 \mathrm{~g} / \mathrm{L}$ or Estimated Glomerular Filtration Rates (eGFRs) $<80 \mathrm{~mL} / \mathrm{mn}$. eGFRs were calculated using the 4-point Modification of Diet in Renal Disease (MDRD) formula. Pulmonary hypertension was defined as a mean pulmonary arterial pressure of at least $25 \mathrm{mmHg}$ confirmed by right heart catheterization, but we did not consider for this analysis whether the elevated pulmonary artery pressures were due to left-sided heart disease (post-capillary) or true pulmonary arterial hypertension (pre-capillary).

Clinical data were collected in 448 patients. Clinical data were available in patients for the absence/presence of skin ulcers $(n=142)$, pulmonary hypertension ( $n=234)$, priapism ( $n=75$ men), renal dysfunction $(n=182)$, stroke $(n=330)$, osteonecrosis $(n=278)$, retinal complication $(n=344)$ and cholecystectomy $(n=186)$. One hundred patients did not have leg ulcers, pulmonary hypertension, priapism, renal dysfunction or stroke. ACS and VOC occurring in the last year (1 year period) were noted in 272 patients. 
Countries of origin were grouped as follows: North Africa (Algeria, Marocco, Tunisia), Central Africa (Central African Republic, Gabon, Congo, Democratic Republic of Congo, Angola), West Africa (Benin, Burkina Faso, Ghana, Guinea, Ivory Coast, Mali, Niger, Nigeria, Senegal, Togo), West Indies (Guadaloupe, French Guiana, Martinique), Indian Ocean (Madagascar, Mauritius, Reunion, Comores Islands), and others.

This study was approved by the local Institutional Review Board (CPP- Creteil). All patients gave their signed informed consent for the genetic studies in accordance with the Declaration of Helsinki. All data were rendered anonymous to protect patients' privacy and confidentiality. Chronically transfused patients were excluded.

\section{Laboratory methods}

Laboratory data were collected during routine outpatient visits. Hematologic data were the means of 2 or 3 separate steady-state determinations. Steady state was defined as a visit $\geq 1$ month after an acute clinical event (VOC, infection, acute chest, or any other clinical event resulting in hospitalization and/or blood transfusion) and $\geq 3$ months after blood transfusion. All patients were receiving folic acid regularly and biological data were not taken into account when iron deficiency was present since it has a clear influence on the density curve, and other hematological parameters. All laboratory analyses were performed on-site in the Clinical Laboratories of the Hôpital Henri Mondor, Creteil.

Hematologic studies. CBC and reticulocytes were measured with a Coulter LH 750 counter (Beckman Coulter Inc., Miami, FL). Measured parameters included mean corpuscular cell volume (MCV), red cell distribution width (RDW), mean corpuscular hemoglobin content $(\mathrm{MCH})$, as well as Hemoglobin $(\mathrm{Hb})$, hematocrit $(\mathrm{Hct})$, and red cell 
count (RBC). Reticulocytes were expressed as either absolute reticulocyte count (cells $10^{9} / \mathrm{L}$ ) or the reticulocyte percentage.

Levels for $\mathrm{HbS}, \mathrm{HbF}$, and $\mathrm{HbA}_{2}$ were determined by cation-exchange high performance liquid chromatography using the Variant $\mathrm{Hb}$ analyzer (Variant Hemoglobin Testing System, BioRad, Hercules, CA).

$R B C$ density measurements. Density was assessed with the phthalate densitydistribution technique. ${ }^{12}$ Phthalate oil mixtures of precise density were prepared by mixing 2 phthalate esters, $n$-butyl phthalate and dimethyl-phthalate, to achieve the following densities $\left(\mathrm{g} / \mathrm{mL}\right.$ at $\left.20^{\circ} \mathrm{C}\right): 1.060,1.064,1.068,1.076,1.080,1.084,1.088$, 1.092, 1.096, 1.100, 1.104, 1.108, 1.112, 1.116, 1.120, 1.124, 1.128, 1.132 and 1.136.

RBC were washed 3 times at $4^{\circ} \mathrm{C}$ with isotonic saline (osmolarity 290-300 mOsm). For each wash, tubes were centrifuged for $5 \mathrm{~min}$ at $3,000 \mathrm{~g}$. After resuspending the RBC pellet, a 50\% suspension was prepared in isotonic saline, which had previously been kept at room temperature and the cells were left to equilibrate at room temperature for $15 \mathrm{~min}$. Then, $0.5-1 \mathrm{~cm}$ of each phthalate oil mixture was placed in a separate glass capillary hematocrit tubes. Using a 1-cc syringe with $26 \mathrm{G}$ needle, each tube was then filled with the patient washed RBC suspension (about $2 \mathrm{~cm}$ ). Particular care was taken to avoid trapping air bubbles in the tubes. Each hematocrit tube was sealed at one end and spun in a temperature-controlled centrifuge $\left(20^{\circ} \mathrm{C}\right)$ at $10,000 \mathrm{~g}$ for $10 \mathrm{~min}$. The height of the RBC column below the oil was measured in each hematocrit tube, using either graph paper or a ruler under a magnifying lens. The percentage of DRBC (below the phthalate oil layer) was calculated as follows: cells below/(cells below + cell above). The results were plotted against density to generate a RBC density distribution curve for each patient. For each of these curves, the DRBC 
percentage was determined as the percentage of RBC with density $>1.120 .{ }^{13}$ The $D_{50}$ was defined as the density for which cells below/(cells below + cell above) was equal to 0.5 .

Biochemical studies. Serum levels of total bilirubin and lactate dehydrogenase (LDH) were determined with a routine chemistry analyzer (Advia 1650, Siemens Medical Solutions Diagnostics, Tarrytown, NY).

Genotype analysis. DNA was isolated from peripheral blood leukocytes by phenol-chloroform extraction. Three forms of deletional $\alpha$-thalassemia $\left(a^{-3.7}, a^{-20.5}\right.$, and Mediterranean type) were ascertained with a polymerase chain reaction (PCR). PCRrestriction fragment length polymorphism (RFLP) was used to determine the $\beta$-globin gene cluster haplotypes. ${ }^{14}$ The polymorphic restriction endonuclease sites studied were: Hincll 58 to the $\varepsilon$ - and 38 to the yß-globin genes, $X m n l(-158) 58$ to the Gy-globin gene, HindIII in the IVS-2 of Gy-and Ay-globin genes, Hinfl 58 and 38 to the $\beta$-globin gene and Rsal 58 to the $\beta$-globin gene. ${ }^{15}$

Haplotypes associated with the $\beta$-globin mutation were designed as Bantu (CAR), Benin, Cameroon, Senegal and others for atypical haplotypes.

\section{Statistical analysis}

Results are expressed as means \pm standard deviation (SD), numbers or percentages, as appropriate. Quantitative parameters were compared between groups by use of a Student's t-test, or a Mann-Whitney U nonparametric test when number of patients $<30$. F-test was used to compare the equality of two variances. Multivariable linear regression models were used to compare $\mathrm{MCV}, \mathrm{HbF}, \mathrm{D} 50$ and $\mathrm{DRBC}$ levels among haplotypes as well as a-thal status. Tukey adjustment for multiple comparisons was applied to both analyses for the pairwise testing. Chi-square test was used to compare 
the numbers of patients with a a-thalassemia deletion among haplotypes. Simple linear regressions were performed for each biologic parameter to search for potential relationship with DRBC. Multiple linear regressions were used to explore models that better predicted RBC density. All the variables (except $D_{50}$ ) related to the hematologic, and biochemical profiles that were significantly correlated with DRBC with an univariate threshold $(P<.05)$ were considered in each model. Models were built using a forward stepwise approach. The final models included the variables that remained significantly associated with RBC density after adjustment for the other variables in the models. Rsquares $\left(r^{2}\right)$ were used as measures of variance explained by the models. Statistical significance was defined as $P$ value less than 0.05 . Correlations were established using Pearson's correlation coefficient. Statistical analysis was conducted with SPSS 17.0, Statview 5.0 and Prism 4. 


\section{Results}

Demographic data are summarized in Table 1. The West Indies, Central Africa and West Africa approximately accounted for each a quarter of the patients. The average patient follow-up was 17.7 years.

The mean $( \pm S D) \% D R B C$ was $12.8( \pm 7.8)$. There was no correlation between the patient age and the \%DRBC $(P=.27)$. There was a trend towards higher \%DRBC in male compared to female, respectively $13.4 \pm 7.9$ and $12.2 \pm 7.6(P=.055)$. The DRBC and $D_{50}$ data were reported in Table 2 . The CAR haplotype was associated with the highest percentage of patients with a-thalassemia deletion, which could explain their having the smallest MCV and lowest $D_{50}$. As previously described, ${ }^{16}$ the Senegal haplotype was associated with the highest $\% \mathrm{HbF}$ and the CAR haplotype with the lowest one.

a-thal status data are presented in Table 3. The presence of a-thalassemia, as either a 1 or 2 gene deletion, was associated with progressive decreases of MCV, HbF, $\mathrm{D}_{50}$ and \%DRBC. Differences between groups for \%DRBC were all significant $(P<.01)$.

Variables significantly correlated with \%DRBC according to our univariate analysis are reported in Table 4. Hemolytic biologic parameters (LDH and bilirubin), WBC and platelet count were positively correlated with DRBC, whereas Hb, Hct, RBC and $\% \mathrm{HbF}$ were negatively correlated. Multivariable analysis showed significantly positive associations with $\mathrm{MCH}, \mathrm{RDW}$, bilirubin, $\mathrm{LDH}$ and negative association with $\% \mathrm{HbF}$ and Hct. This statistical model accounts for $\sim 40 \%$ of variability of DRBC in SS patients.

Table 5 shows clinical and biological associations. \%DRBC were significantly higher in patients with skin ulcers, priapism or renal dysfunction than either the entire 
data set or in a subgroup of patients with none of these complications. Those associations were not explained by differences in \% $\mathrm{HbF}$.

The mean \%DRBC decreased by $34 \%(\mathrm{n}=33, P=.02)$ after 6 months of hydroxycarbamide treatment, despite an increase in $D_{50}$ (Figure 1). The \%DRBC distribution was more homogenous under $\mathrm{HC}$ than before treatment, as proved by variances difference $(P=.004)$. Interestingly, the change in DRBC\% was not correlated with the increase level in $\mathrm{HbF} \%(P=.58)$ 


\section{Discussion}

Prior studies on the clinical correlates of dense cells were hampered by the small number of patients and the lack of rigorous laboratory assessments. In the present study, all laboratory analyses were conducted under homogenous conditions, using standardized procedures on patients who were all followed in our SCD Referral Center for more than 1 year. RBC density was directly measured in each patient at steady state with the phthalate-density method. The validity and reproducibility of this technique in SCD have been previously confirmed ${ }^{17}$ and does not depend on the patient age.

Our results demonstrate for the first time in a large cohort of patients, that the \%DRBC is specifically associated with defined clinical complications of the disease and with $\mathrm{HbS}$ polymerization contributing factors (Table 4 and 5). The percentage of DRBC, which is the important measure, is very easy to perform and needs only one hematocrit tube. However a temperature controlled centrifuge must be used, which could be a limiting factor for wider applicability of this assay. The reproducibility is excellent with no difference between two analyses with a mean interval of 3 years $(n=26$ patients, $P=.79)$; the mean \%DRBC of the first and the second analysis were respectively $15.5 \pm 8.4$ and $15.8 \pm 8.1$. Linear regression analysis of duplicate measures yielded an $R^{2}$ value of $0.6468(p<0.0001)$. We have confirmed in a large cohort that DRBCs are correlated with biologic parameters of hemolysis: positively with LDH, bilirubin and \%reticulocytes, and negatively with Hct. Enhanced hemolysis might be related to mechanical destruction because of rheological anomalies due to $\mathrm{HbS}$ polymerization ${ }^{8}$ and/or because of immune-mediated destruction due to defective control of membrane attack complex against DRBC, ${ }^{18}$ membrane abnormalities ${ }^{19}$ and increased DRBC opsonization by autologous immunoglobulin. ${ }^{20}$ 
The \%DRBC is significantly associated with hematological parameters like $\mathrm{MCH}, \mathrm{RDW}$, and \% $\mathrm{Hb} F$ (Table 4). Cell hemoglobin concentration is known to directly influence the rate of $\mathrm{HbS}$ polymerization, ${ }^{3,4}$ particularly under deoxygenated conditions. ${ }^{21,22}$ DRBC formation is not completely understood, but some studies argue strongly for a direct relationship between $\mathrm{HbS}$ polymerization and DRBC formation, ${ }^{22-24}$ mediated in part, by erythrocyte dehydration due to $\mathrm{K}^{+}$loss. ${ }^{2,25,26}$ Other observations also support the hypothesis that DRBC are not the result of aging per se, as young cells including reticulocytes could be transformed into DRBC. ${ }^{27}$ DRBC are in a dynamic equilibrium between the processes leading to their formation and those responsible for their removal. Erythrocyte lifespan is shortest in patients with the highest numbers of DRBC ${ }^{17}$ with survival half-time of 40 hours for DRBC with the lowest $\mathrm{HbF}$ content. ${ }^{28}$

Studies on small patients cohorts have shown reduced numbers of DRBC in $\mathrm{HbS} / \mathrm{a}$-thalassemia patients and patients with elevated $\mathrm{HbF}$ levels. ${ }^{9,29-32} \mathrm{HbF}$ directly inhibits HbS polymerization ${ }^{33}$ and also decreases RBC dehydration. ${ }^{9,34}$ Concomitant $\alpha$ thalassemia and SCD has been described to be associated with fewer complications related to hemolytic phenotype. ${ }^{29,35-37}$ Our data demonstrated that a-thalassemia had a significant biological effect by reducing the \%DRBC in SS disease (Table 3). Despite those correlations, it is intriguing that the haplotypes with the highest $\mathrm{HbF}$ percentage (Senegal/Senegal) and the highest percentage of patients with $\alpha$-thalassemia deletion (CAR/CAR) were not those with the lowest mean \%DRBC. These differences might be explained on the one hand by the Senegal haplotype being associated with a lower percentage of a-thalassemia deletions or the CAR haplotype being associated with a lower \%HbF. Interestingly, in the Bantou/Bantou haplotype the $\% \mathrm{HbF}$ was not associated with the \%DRBC whereas the relationship with a-thalassemia deletions was 
strong $(\mathrm{P}<.0001)$. However, we cannot exclude the possibility of a false positive finding as we performed multiple hypothesis tests that may increase the probability of type I errors.

We also reported here a relationship between the \%DRBC and WBC count in the univariate but not in the multivariable analysis, meaning that \%DRBC had no independent predictive utility when considering $\mathrm{MCH}$, RDW, bilirubin, $\mathrm{LDH}, \% \mathrm{HbF}$, and Hct simultaneously. WBC count has been shown to be a strong, independent predictor of acute chest syndrome,$^{38}$ stroke, ${ }^{39,40}$ and overall SCD severity in children. ${ }^{41}$

We demonstrated here for the first time that \%DRBC are associated with skin ulcers, priapism and renal dysfunction. In our dataset enhanced hemolysis, as demonstrated by higher LDH levels, was present only in patients with pulmonary hypertension and renal dysfunction but not in patients with priapism or skin ulcers whereas these clinical manifestations have been described to be associated with hemolysis biologic parameters. ${ }^{42,43}$ The strong association of \%DRBC with skin ulcers and priapism in the absence of increased LDH could suggest that intrinsic cellular characteristics of DRBC may be involved in the pathophysiology of these complications. Kaul and colleagues demonstrated that increased viscosity was correlated with increased cell density and that deoxygenation dramatically increased the DRBC fractions and, subsequently, peripheral vascular resistance. ${ }^{44}$ Although less adherent to vasculature ${ }^{45,46}$ DRBCs caused persistent blockage of small postcapillary venules in an ex vivo model, ${ }^{45,47}$ and were more prone to being trapped, in vivo, with acute effects resulting in perfusion deficits followed by metabolic as shown by ${ }^{99} \mathrm{mTc}$ imaging and magnetic resonance spectroscopy. ${ }^{48}$ More recently, the extent of mechanical deformation of the RBC membrane was demonstrated to control shear-induced ATP 
release, and regulate blood pressure by releasing ATP as a vasodilatory signaling molecule; therefore, increased RBC rigidity, could be responsible for impaired ATP delivery and could favor vasoconstriction. ${ }^{49}$

Hydrocarbamide, the only drug with clinical proven benefit in SCD, significantly decreases the \%DRBC after 6 months of therapy without a correlation with $\mathrm{HbF} \%$ increase (Fig. 1). Since \%DRBC could be involved in the pathophysiology of skin ulcers, priapism and renal dysfunction, $\mathrm{HC}$ use with the aim of reaching a sharp decrease in DRBC\%, should be prospectively evaluated in clinical trials for patients with these specific complications. Drugs which specifically inhibit sickle cell dehydration, resulting in significantly lower \%DRBC, and concomitantly less hemolysis and anemia, should also be reconsidered for patients with high \%DRBC and skin ulcers, priapism or renal dysfunction, perhaps in conjunction with phlebotomy to prevent excessive increases in $\mathrm{Hb}$ levels. ${ }^{50}$

Our study highlights the notion that simple determination of the \%DRBC can be a meaningful and useful addition to the hematological characterization of patients with sickle cell syndromes. New studies to establish the clinical utility of this test in guiding therapeutic approaches are needed. 


\section{Acknowledgments}

We thank Jugurtha Berkenou and Christine Fauroux for the data management; and Orah Platt, Janet Jacobson, Gil Tchernia, Marie Cambot and Henri Wajcman for helpful feedback and discussions.

\section{Author Contributions:}

Pablo Bartolucci: analyzed, interpreted data, performed statistical analysis and wrote the manuscript.

Carlo Brugnara: analyzed and interpreted data, edited manuscript.

Armando Teixeira Pinto: performed the statistical analysis.

Serge Pissard, Kamran Moradkhani and Hélène Jouault: conducted laboratory tests.

Frédéric Galactéros: designed the study, collected and interpreted data.

Conflict of interest Disclosure: none 


\section{References}

1. Brugnara C, Bunn HF, Tosteson DC. Regulation of erythrocyte cation and water content in sickle cell anemia. Science. 1986;232(4748):388-390.

2. Fabry ME, Romero JR, Buchanan ID, et al. Rapid Increase In Red-Blood-Cell Density Driven By K-Cl Cotransport In A Subset Of Sickle-Cell-Anemia Reticulocytes And Discocytes. Blood. 1991;78(1):217-225.

3. Eaton WA, Hofrichter J. Sickle cell hemoglobin polymerization. Adv Prot Chem. 1990;40:63-279.

4. Sunshine HR, Hofrichter J, Eaton WA. Requirements for therapeutic inhibition of sickle hemoglobin gelation. Nature. 1978;275:238-240.

5. Bridges KR, Barabino GD, Brugnara $\mathrm{C}$, et al. A multiparameter analysis of sickle erythrocytes in patients undergoing hydroxyurea therapy. Blood. 1996;88(12):47014710.

6. Fabry ME, Nagel RL. Heterogeneity of red cells in the sickler: a characteristic with practical clinical and pathophysiological implications. Blood Cells. 1982;8(1):9-15. 7. Messmann R, Gannon S, Sarnaik S, Johnson RM. Mechanical properties of sickle cell membranes. Blood. 1990;75(8):1711-1717.

8. Clark MR, Mohandas N, Shohet SB. Deformability of oxygenated irreversibly sickled cells. J Clin Invest. 1980;65(1):189-196.

9. Fabry ME, Mears JG, Patel P, et al. Dense cells in sickle cell anemia: the effects of gene interaction. Blood. 1984;64(5):1042-1046.

10. Billett HH, Kim K, Fabry ME, Nagel RL. The percentage of dense red cells does not predict incidence of sickle cell painful crisis. Blood. 1986;68(1):301-303.

11. Ballas SK, Larner J, Smith ED, Surrey S, Schwartz E, Rappaport EF. Rheologic predictors of the severity of the painful sickle cell crisis. Blood. 1988;72(4):1216-1223.

12. Danon D, Marikovsky Y. Determination of density distribution of red cell population. Journal of Laboratory and Clinical Medicine. 1964;64:668-673.

13. De Franceschi L, Bachir D, Galacteros F, et al. Oral magnesium supplements reduce erythrocyte dehydration in patients with sickle cell disease. Journal of Clinical Investigation. 1997;100(7):1847-1852.

14. Sutton M BE, Nagel RL. polymerase chain reaction amplification applied to the determination of beta-like globin gene cluster haplotypes. american journal of hematology. 1989;32(1):66-69.

15. Lee K, Prehu C, Merault G, et al. Genetic and hematological studies in a group of 114 adult patients with SC sickle cell disease. Am J Hematol. 1998;59(1):15-21.

16. Green NS, Fabry ME, Kaptue-Noche L, Nagel RL. Senegal haplotype is associated with higher $\mathrm{HbF}$ than Benin and Cameroon haplotypes in African children with sickle cell anemia. American Journal of Hematology. 1993;44(2):145-146.

17. Serjeant GR, Serjeant BE, Milner PF. The irreversibly sickled cell; a determinant of hemolysis in sickle cell anemia. Br J Haematol. 1969;17:527-533.

18. Test ST, Woolworth VS. Defective regulation of complement by the sickle erythrocyte: evidence for a defect in control of membrane attack complex formation. Blood. 1994;83:842-852. 
19. Corbett JD, Golan DE. Band 3 and glycophorin are progressively aggregated in density-fractionated sickle and normal red blood cells. Evidence from rotational and lateral mobility studies. J Clin Invest. 1993;91(1):208-217.

20. Low PS, Waugh SM, Zinke K, Drenckhahn D. The role of hemoglobin denaturation and band 3 clustering in red blood cell aging. Science. 1985;227(4686):531-533.

21. Noguchi CT, Torchia DA, Schechter AN. Determination of deoxyhemoglobin S polymer in sickle erythrocytes upon deoxygenation. Proc Natl Acad Sci U S A. 1980;77(9):5487-5491.

22. Keidan AJ, Sowter MC, Johnson CS, et al. Effect of polymerization tendency on haematological, rheological and clinical parameters in sickle cell anaemia. $\mathrm{Br} J$ Haematol. 1989;71(4):551-557.

23. Seakins M, Gibbs WN, Milner PF, Bertles JF. Erythrocyte Hb-S concentration. An important factor in the low oxygen affinity of blood in sickle cell anemia. $\mathrm{J}$ Clin Invest. 1973;52(2):422-432.

24. Clark MR, Shohet SB. The effect of abnormal hemoglobins on the membrane regulation of cell hydration. Tex Rep Biol Med. 1980;40:417-429.

25. Brugnara $\mathrm{C}$, Van Ha T, Tosteson DC. Acid pH induces formation of dense cells in sickle erythrocytes. Blood. 1989;74(1):487-495.

26. Schwartz RS, Musto S, Fabry ME, Nagel RL. Two distinct pathways mediate the formation of intermediate density cells and hyperdense cells from normal density sickle red blood cells. Blood. 1998;92(12):4844-4855.

27. Bookchin RM, Ortiz OE, Lew VL. Evidence for a direct reticulocyte origin of dense red cells in sickle cell anemia. J Clin Invest. 1991;87(1):113-124.

28. Franco RS, Yasin Z, Lohmann JM, et al. The survival characteristics of dense sickle cells. Blood. 2000;96(10):3610-3617.

29. Embury SH, Dozy AM, Miller J, et al. Concurrent Sickle-Cell-Anemia And AlphaThalassemia - Effect On Severity Of Anemia. New Engl JMed. 1982;306(5):270-274. 30. Embury SH, Clark MR, Monroy G, Mohandas N. Concurrent sickle cell anemia and alpha-thalassemia. Effect on pathological properties of sickle erythrocytes. Journal of Clinical Investigation. 1984;73(1):116-123.

31. Milner PF, Garbutt GJ, Nolandavis LV, Jonah F, Wilson LB, Wilson JT. The Effect Of Hb F And Alpha-Thalassemia On The Red-Cell Indexes In Sickle-Cell-Anemia. Am J Hematol. 1986;21(4):383-395.

32. Baudin V, Pagnier J, Labie D, Girot R, Wajcman H. Heterogeneity of sickle cell disease as shown by density profiles: effects of fetal hemoglobin and alpha thalassemia. Haematologia (Budap). 1986;19(3):177-184.

33. Nagel RL, Bookchin RM, Johnson J, et al. Structural bases of the inhibitory effects of hemoglobin $\mathrm{F}$ and hemoglobin $\mathrm{A} 2$ on the polymerization of hemoglobin $\mathrm{S}$. Proc Nat Acad Sci USA. 1979;76(2):670-672.

34. Fabry ME, Romero JR, Buchanan ID, et al. Rapid increase in red blood cell density driven by $\mathrm{K}: \mathrm{Cl}$ cotransport in a subset of sickle cell anemia reticulocytes and discocytes. Blood. 1991;78(1):217-225.

35. Fabry ME, Benjamin L, Lawrence C, Nagel RL. An objective sign in painful crisis in sickle cell anemia: the concomitant reduction of high density red cells. Blood. 1984;64(2):559-563. 
36. Higgs DR, Aldridge BE, Lamb J, et a. The interaction of alpha-thalassemia and homozygous sickle-cell disease. New Engl J Med. 1982;306(24):1441.

37. Steinberg MH, Hebbel RP. Clinical diversity of sickle cell anemia: genetic and cellular modulation of disease severity. Am J Hematol. 1983;14(4):405-416.

38. Castro O, Brambilla DJ, Thorington B, et al. The acute chest syndrome in sickle cell disease: incidence and risk factors. The Cooperative Study of Sickle Cell Disease. Blood. 1994;84:643-649.

39. Ohene-Frempong K, Weiner SJ, Sleeper LA, et al. Cerebrovascular accidents in sickle cell disease: rates and risk factors. Blood. 1998;91(1):288-294.

40. Gillum RF, Ingram DD, Makuc DM. White blood cell count and stroke incidence and death. The NHANES I epidemiologic follow-up study. Am J Epidemiol. 1994;139(9):894-902.

41. Miller ST, Sleeper LA, Pegelow CH, et al. Prediction of adverse outcomes in children with sickle cell disease. New Engl J Med. 2000;342(2):83-89.

42. Kato GJ, Gladwin MT, Steinberg MH. Deconstructing sickle cell disease: reappraisal of the role of hemolysis in the development of clinical subphenotypes. Blood 2007;21(1):37-47.

43. Nolan VG, Adewoye A, Baldwin C, et al. Sickle cell leg ulcers: associations with haemolysis and SNPs in Klotho, TEK and genes of the TGF-beta/BMP pathway. Bri J Haematol. 2006;133(5):570-578.

44. Kaul DK, Fabry ME, Windisch P, Baez S, Nagel RL. Erythrocytes in sickle cell anemia are heterogeneous in their rheological and hemodynamic characteristics. J Clinlnvest. 1983;72(1):22-31.

45. Kaul DK, Chen D, Zhan J. Adhesion of sickle cells to vascular endothelium is critically dependent on changes in density and shape of the cells. Blood. 1994;83:30063017.

46. Kaul DK, Fabry ME, Nagel RL. Microvascular sites and characteristics of sickle cell adhesion to vascular endothelium in shear flow conditions: pathophysiological implications. Proc Nat Acad Sci USA. 1989;86(9):3356-3360.

47. Kaul DK, Fabry ME, Nagel RL. Vaso-occlusion by sickle cells: evidence for selective trapping of dense red cells. Blood. 1986;68:1162-1166.

48. Fabry ME, Rajanayagam V, Fine $\mathrm{E}$, et al. Modeling sickle cell vasoocclusion in the rat leg: quantification of trapped sickle cells and correlation with 31P metabolic and 1H magnetic resonance imaging changes. Proc Nat Acad Sci USA 1989;86(10):38083812.

49. Wan J, Ristenpart WD, Stone HA. Dynamics of shear-induced ATP release from red blood cells. Proc Natl Acad Sci U S A. 2008;105(43):16432-16437.

50. Ataga KI, DeCastro LM, Swerdlow P, Saunthararajay Y, Smith W. Efficacy and safety of the Gardos channel inhibitor, ICA-17043, in patients with sickle cell anemia. Blood. 2004;104:33a. 


\section{Table 1. Socio-demographic characteristics}

\begin{tabular}{llr}
\hline \multicolumn{1}{c}{ Characteristic } & \multicolumn{2}{c}{ SS } \\
\hline $\begin{array}{l}\text { Sex, no.(\%) } \\
\text { Female }\end{array}$ & 342 & $(58)$ \\
$\quad$ Male & 246 & $(42)$ \\
Country, no.(\%) & & \\
$\quad$ West Africa & 226 & $(38)$ \\
$\quad$ West Indies & 175 & $(30)$ \\
$\quad$ Central Africa & 160 & $(27)$ \\
$\quad$ North Africa & 11 & $(2)$ \\
$\quad$ Others & 16 & $(3)$ \\
$\begin{array}{l}\text { Age (yrs), mean } \pm S D \\
\text { [range] }\end{array}$ & \multicolumn{2}{c}{$41 \pm 9$ [19, 71] } \\
BMI, mean $\pm S D$ & \multicolumn{2}{c}{$21 \pm 3[15,32]$} \\
[range]
\end{tabular}

Table 2. The effects of haplotypes on MCV, HbF, $\mathrm{D}_{50}$ and \%DRBC.

\begin{tabular}{|c|c|c|c|c|c|c|c|c|}
\hline \multirow{2}{*}{$\begin{array}{l}\text { Patients } \\
\text { Haplotype }\end{array}$} & \multirow[b]{2}{*}{$\mathbf{n}$} & \multicolumn{2}{|c|}{ MCV } & \multicolumn{2}{|c|}{$\% \mathrm{HbF}$} & \multirow{2}{*}{$\begin{array}{l}\alpha \text {-Thal del } \\
\% \text { patients }\end{array}$} & D50 & \multirow{2}{*}{$\begin{array}{r}\% \text { DRBC } \\
\text { Mean } \pm S D\end{array}$} \\
\hline & & \multicolumn{2}{|c|}{ Mean \pm SD } & \multicolumn{2}{|c|}{ Mean \pm SD } & & Mean \pm SD & \\
\hline Benin/Benin & 200 & $88.7^{*}$ & \pm 9.6 & $7.4^{*}$ & \pm 5.2 & $49^{*} \dagger$ & $1.096^{*} \pm 0.003$ & $13.4 \pm 7.7$ \\
\hline Benin/CAR & 33 & 88.1 & \pm 6.7 & $7.0^{\dagger}$ & \pm 5.5 & $42^{\ddagger}$ & $1.096 \pm 0.003$ & $14.8 \pm 9.6$ \\
\hline Benin/Cameroon & 24 & 83.8 & \pm 10.2 & $5.9^{\ddagger}$ & \pm 3.7 & 42 & $1.095 \pm 0.003$ & $9.8 \pm 7.5$ \\
\hline Benin/Senegal & 31 & 88.6 & \pm 9.6 & $9.6^{\S}$ & \pm 6.2 & $35^{\S}$ & $1.096 \pm 0.003$ & $13.3 \pm 7.8$ \\
\hline CAR/CAR & 134 & $83.2^{* t \ddagger}$ & \pm 9.9 & 5.7 *\$币 & \pm 4.4 & $64^{\star ‡ \S}$ & $1.095^{\star} \pm 0.003$ & $11.3 \pm 7.4$ \\
\hline Senegal/Senegal & 38 & $91.5^{\dagger}$ & \pm 11.1 & $11.7^{* t \neq \rrbracket \#}$ & \pm 5.9 & $29^{*} \dagger$ & $1.097^{\dagger} \pm 0.002$ & $13.0 \pm 7.2$ \\
\hline Other & 40 & $89.2^{\ddagger}$ & \pm 8.6 & $7.2^{\#}$ & \pm 4.7 & 50 & $1.096 \pm 0.003$ & $13.2 \pm 7.8$ \\
\hline
\end{tabular}

The superscript numbers indicate significant differences between the means sharing the same number. For example, the mean of MCV for SS patients with Benin/Benin haplotype is significantly different from the mean of patients with CAR/CAR haplotype. The statistical significance, defined as $P<.05$, was obtained with ANOVA test and Tukey adjustment for multiple comparisons, and $\mathrm{Chi}^{2}$ test for a status when authorized 
Table 3. MCV, HbF, $D_{50}$ and \%DRBC by a-thalassemia status

\begin{tabular}{|c|c|c|c|c|c|c|c|c|c|}
\hline \multirow{2}{*}{$\begin{array}{c}\text { a-thalassemia } \\
\text { status }\end{array}$} & \multirow[b]{2}{*}{$\mathbf{n}$} & \multirow{2}{*}{\multicolumn{2}{|c|}{$\frac{\text { MCV }}{\text { Mean } \pm \text { SD }}$}} & \multirow{2}{*}{\multicolumn{2}{|c|}{$\begin{array}{c}\mathrm{HbF} \\
\text { Mean } \pm S D\end{array}$}} & \multirow{2}{*}{\multicolumn{2}{|c|}{$\begin{array}{c}\mathrm{D}_{50} \\
\text { Mean } \pm \text { SD }\end{array}$}} & \multirow{2}{*}{\multicolumn{2}{|c|}{$\begin{array}{c}\% \text { DRBC } \\
\text { Mean } \pm \text { SD }\end{array}$}} \\
\hline & & & & & & & & & \\
\hline Normal & 216 & $92.6^{*} \dagger$ & \pm 8.6 & $8.4^{*}$ & \pm 5.7 & $1.096^{*}$ & \pm 0.003 & $14.6^{*}$ & \pm 7.7 \\
\hline 1 gene deletion & 183 & $84.6^{*} \neq$ & \pm 6.8 & $6.8^{*}$ & \pm 4.7 & $1.095^{*}$ & \pm 0.003 & $12.5^{\star}$ & \pm 7.3 \\
\hline 2 gene deletions & 46 & $71.1^{\dagger \ddagger}$ & \pm 4.4 & $4.4^{\star}$ & \pm 3.7 & $1.092^{* \dagger}$ & \pm 0.003 & $4.5^{* \dagger}$ & \pm 4.3 \\
\hline Gene triplication & 7 & $92.4^{\ddagger}$ & \pm 7.9 & 7.8 & \pm 4.8 & $1.098^{\dagger}$ & \pm 0.002 & $16.9^{\dagger}$ & \pm 4.8 \\
\hline
\end{tabular}

The superscript numbers indicate significant differences between the means sharing the same number. For example, the mean MCV for SS patients with normal a-thalassemia status differed significantly from that of patients with 1 or 2 gene deletions. The statistical significance, defined as $P<.05$, were pairwise comparisons using the Tukey adjustment. 
Table 4. Biologic parameters associated with \% DRBC on 588 patients

\begin{tabular}{|c|c|c|}
\hline Parameter & $\begin{array}{c}\text { Univariate } \\
\text { analysis } \\
\text { Pearson's r } \\
P \text {-Value }\end{array}$ & $\begin{array}{c}\text { Multivariable } \\
\text { analysis } \\
r^{2}=0.38 \\
P<.0001 \\
\text { beta }(\mathrm{SE})\end{array}$ \\
\hline$D_{50}$ & $\begin{array}{l}0.53 \\
<.001\end{array}$ & \\
\hline $\mathrm{Hb}$ & $\begin{array}{l}-0.31 \\
<.001\end{array}$ & \\
\hline Hct & $\begin{array}{l}-0.40 \\
<.001\end{array}$ & $\begin{array}{l}-2.0 \\
(0.4)\end{array}$ \\
\hline RBC & $\begin{array}{l}-0.42 \\
<.001\end{array}$ & \\
\hline MCV & $\begin{array}{l}0.18 \\
<.001\end{array}$ & \\
\hline $\mathrm{MCH}$ & $\begin{array}{l}0.30 \\
<.001\end{array}$ & $\begin{array}{l}0.76 \\
(0.92)\end{array}$ \\
\hline RDW & $\begin{array}{l}0.37 \\
<.001\end{array}$ & $\begin{array}{l}0.46 \\
(0.10)\end{array}$ \\
\hline \%Reticulocyte & $\begin{array}{l}0.37 \\
<.001\end{array}$ & \\
\hline WBC & $\begin{array}{l}0.19 \\
<.001\end{array}$ & \\
\hline Platelet count & $\begin{array}{l}0.15 \\
<.001\end{array}$ & \\
\hline LDH & $\begin{array}{l}0.43 \\
<.001\end{array}$ & $\begin{array}{l}0.014 \\
(0.002)\end{array}$ \\
\hline Bilirubin & $\begin{array}{l}0.30 \\
<.001\end{array}$ & $\begin{array}{c}0.021 \\
(0.01)\end{array}$ \\
\hline$\% \mathrm{HbF}$ & $\begin{array}{l}-0.22 \\
<.001\end{array}$ & $\begin{array}{c}-0.37 \\
(0.07)\end{array}$ \\
\hline
\end{tabular}

SE: standard error of the coefficients

Beta: regression coefficient of the multivariable models indicating the average increase on \%DRBC per one unit increase in the covariate 
Table 5. Biological characteristics of clinical complications

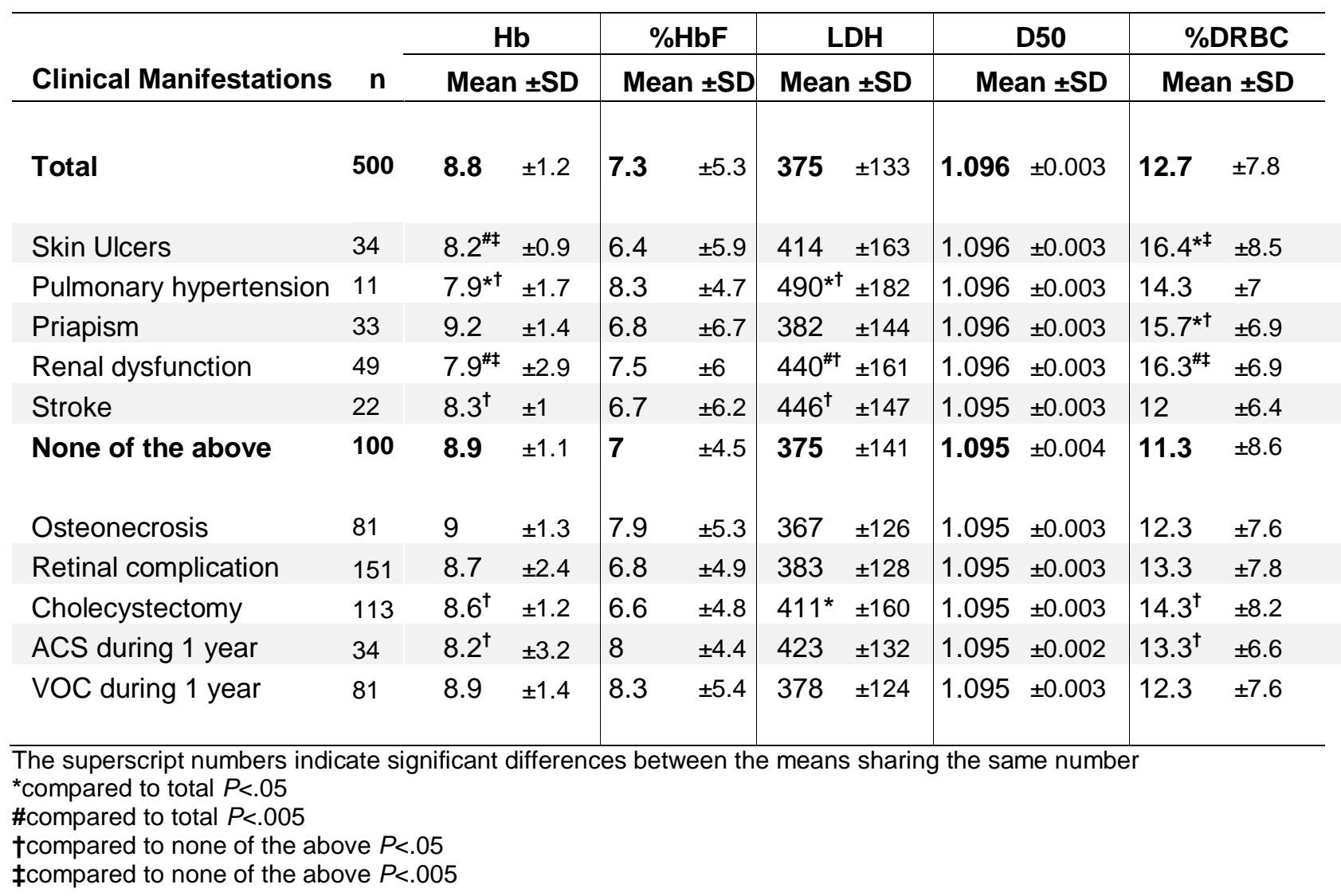




\section{Figure Legend:}

Figure 1: Effects on $D_{50}(A)$ and DRBC (B) after 6 months of hydroxycarbamide therapy. Values for $\mathrm{D}_{50}$ and \% RBDC ( \pm SD) for 33 patients with $\mathrm{Hb}$ SS disease are plotted at baseline and following 6 month of hydroxycarbamide therapy.

\section{Figure 1}
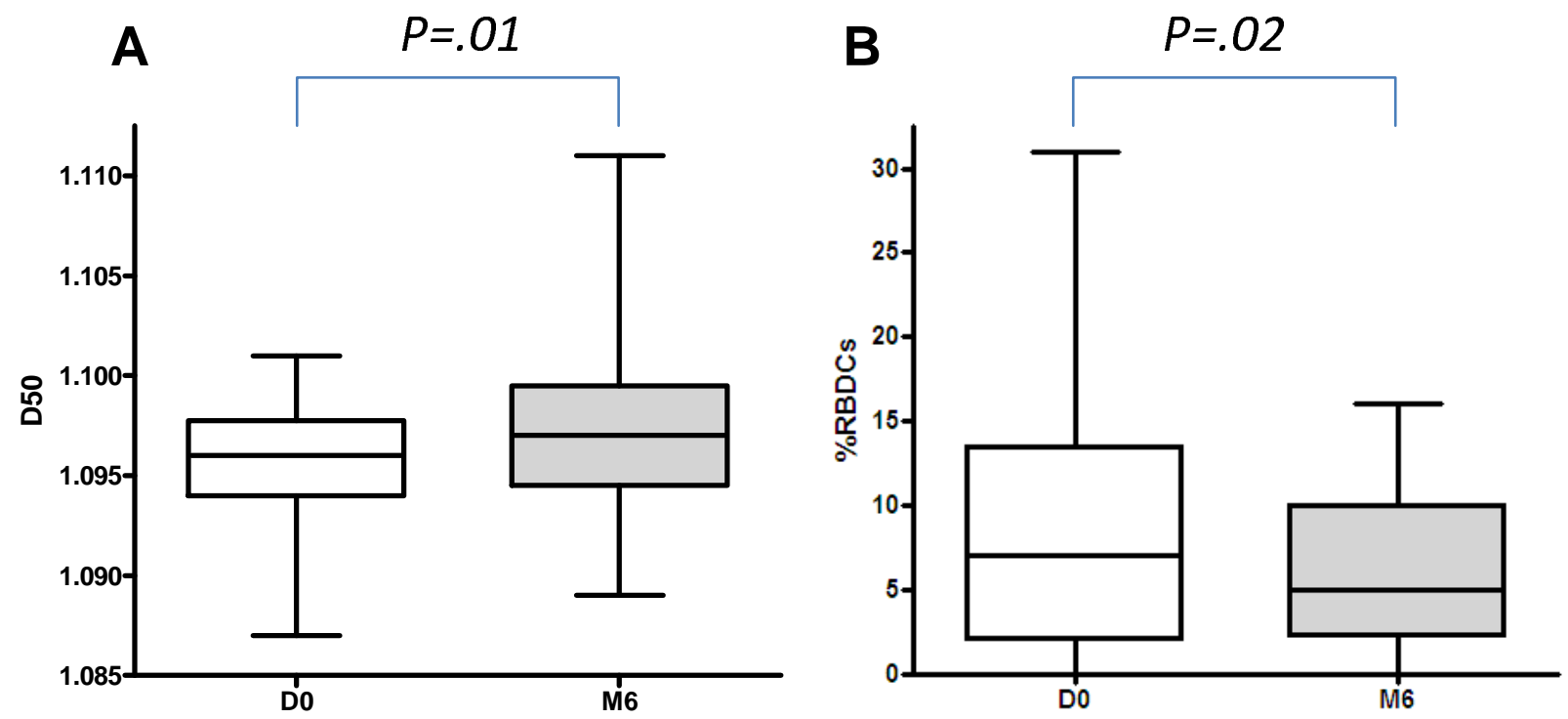